\title{
Aponogetonaceae of Australia, with descriptions of six new taxa
}

\author{
C. B. Hellquist and S.W. L. Jacobs
}

\begin{abstract}
Hellquist, C. B. ${ }^{1}$ and Jacobs, S.W.L. ${ }^{2}\left({ }^{1}\right.$ Department of Biology, Massachusetts College of Liberal Arts, North Adams, MA 01247-4100, USA; ${ }^{2}$ Royal Botanic Gardens, Sydney, NSW, Australia 2000) 1998. Aponogetonaceae of Australia, with descriptions of six new taxa. Telopea 8(1): 7-19. Ten species of Aponogeton (Aponogetonaceae) are recognised from Australia, five of which are described here for the first time: Aponogeton kimberleyensis, A. lancesmithii, A. euryspermus, A. proliferus, and A. vanbruggenii. Two subspecies of A. elongatus are also recognised: A. elongatus subsp. elongatus and the newly described A. elongatus subsp. fluitans.
\end{abstract}

\section{Introduction}

While preparing the treatment of the family Aponogetonaceae for the Flora of Australia it became obvious that neither the material being received from commercial suppliers of aquarium plants nor the herbarium specimens could be adequately dealt with by existing treatments. Bruggen $(1969,1973,1985)$ is the acknowledged authority on the family and his pioneering studies have been responsible for an increased interest in species of Aponogeton and a large increase in field observations and the number of specimens available for study. Aston (1973) is the only Australian author to treat the genus in any detail and she did not have the opportunity to study the genus in the field. Bruggen (1969) was clearly aware of some of the problems as can be seen from his treatment of $A$. elongatus where his forms are rather mixed; in one case he cites the same specimen under two different forms and in another cites duplicates under different forms. His notes clearly state that he was uncertain about this group and it is indeed from this group that all of the new taxa are here separated. The problems with the taxa seem to have been exacerbated by the use of floating versus submerged leaves (Bruggen 1969) as a major key character. This is a good character for some of our species but specimens from some tropical localities were being identified as one species at one time of the year, and another species later in the year. The three species from the wet/dry tropics described here (A. kimberleyensis, A. euryspermus and $A$. vanbruggenii) produce submerged leaves in flowing or clear water and, as the water becomes more turbid from mud or algae, or is shaded, produce more floating leaves. This character is hard to quantify but, as we examined the specimens, it became obvious that there were correlated seed characters that were easier to quantify.

Bruggen $(1969,1985)$ was fortunate in being able to rely heavily on cultivated plants. We had several opportunities to examine plants in the field and the benefit of help from Lance Smith in cultivating many of the species. It appears that some of the difficulties that we had with characters listed in Bruggen (1985) relate to the difference between having fresh cultivated specimens available for study as opposed to relying on dried and pickled herbarium specimens. In the same publication, Bouman (1985) makes it clear that some of the embryo characters are not as clear-cut as presenting them graphically may suggest. At least in the Australian species, germination seems to be a continuous process. If ripe, shed seed can be collected from all species then 
comparisons of characters like the plumule can be useful. By contrast, the seed coat characters can be useful over a wider range of maturity and have been important in helping us delimit taxa.

\section{The characters}

Inflorescence: the inflorescence is usually either a solitary spike (most Australian species) or forked (A. distachyos and A. hexatepalus and rarely in A. lancesmithii). In $A$. hexatepalus there may be further branching. The flowers and inflorescences of all native species are yellow or greenish yellow, the introduced A. distachyos being white or pinkish.

The axis itself is often pithy and helps the inflorescence float. In some species growing in flowing water, the tip of the axis is bent upwards, exposing the young flowers to the air.

It is only the introduced $A$. distachyos that has its flowers arranged fairly closely on one side of each branch of the forked inflorescence. The native species have the flowers arranged right around the axis. In A. bullosus, where the inflorescences are rarely exposed, and in $A$. queenslandicus, which normally grows in still water, the flowers are usually always tightly packed. In $A$. hexatepalus, which also usually grows in still water, the flowers are well-spaced. In the other native species the density of the flowers depends on conditions. In still, shallow water with a stable water depth, the flowers are usually densely packed. If there is a rise in water level, or an increase in flow, after flowering has started, this is usually countered by an elongation of the axis rather than by a further extension of the peduncle. In these specimens the flowers are well-spaced. Consequently these characters are of only limited use in delimiting species.

Leaves: great variability exists within species and populations of the various taxa. Many of the species, especially A. elongatus, A. euryspermus, and A. vanbruggenii, often grow in fast-moving waters of creeks and rivers and, in these situations, often have much longer leaves. The streams and rivers are also often heavily shaded. Plants growing in deep shade usually have thin leaves that are much wider and thinner than those growing in the sun. Leaves in the deep shade may tend to be more ovate than broadly lanceolate. Most of the specimens have distinctive raised glands or punctae along the leaves and occasionally the petioles. Leaf anatomy and morphology have been summarised by Tomlinson (1982) and Baas (1985). Distinctive hydropoten, or localised regions of flat cells that appear as blotches, occur on many plants (Tomlinson 1982). Leaf venation is not distinctive. Two species, A. bullosus and A. lancesmithii, have bullate, or crinkled leaves, variously developed in the latter species.

Floating leaves are especially characteristic of $A$. distachyos, A. hexatepalus, A. queenslandicus and A. elongatus subsp. fluitans. Many of the others will produce them at certain times. However, A. bullosus, A. lancesmithii, and A. proliferus have not been observed producing floating leaves, and $A$. elongatus subsp. elongatus produces them only rarely.

Submersed leaf margins are either undulate or flat. Aponogeton elongatus, A. bullosus, and $A$. lancesmithii have leaf margins that are almost consistently undulate. Occasionally A. euryspermus and $A$. vanbruggenii produce undulate leaves.

Submersed leaf tips and bases are not really useful characters. Most of the leaf tips are obtuse, and the bases are cuneate, but many other variations and combinations of leaf tips occur.

Floating leaf tips and bases are, however, useful in distinguishing A. queenslandicus with its characteristic cordate leaf bases. 
Peduncle: in most species the length of the peduncle is directly dependant on both water depth and speed of flow, length being increased with increases in both. The exception is A. bullosus, in which the inflorescence is frequently never exposed above the water, good fruit set being achieved without the flowers being exposed. In other Australian species fruit is usually not set if the flowers are not exposed above water.

The apex of the peduncle immediately below the inflorescence may be expanded or not. This does not appear to be a reliable character as it seems to depend on the environment, expanded apices being much more common in flowing water where the inflorescences are not exposed. Species that commonly lack expanded peduncle apices include A. bullosus, A. queenslandicus and A. vanbruggenii.

Plumule: Bruggen (1985) states that the plumule may be covered by the cotyledonary sheath and never be visible or it may be variously developed and visible in different species. We found this character to be very variable on herbarium specimens and apparently related to the stage of maturity, the more mature the seed the greater the probability of finding a plumule or a groove. In all cases we found it preferable to remove any seed coats before looking for a plumule. Because of the limited value of this character in herbarium specimens we did not use it to delimit species but we provide relevant information in the description.

Seeds: seeds provide the best diagnostic characters to distinguish many of the taxa. There are differences in size, shape and number per carpel. Of the Australian species, A. euryspermus has the largest seeds (to about $5 \mathrm{~mm}$ long, almost ovoid, and usually only 1-3(-5) per carpel), and A. kimberleyensis (1-1.5 $\mathrm{mm}$ ) and A. elongatus (1-3 $\mathrm{mm})$ the smallest. A. queenslandicus has a large number (4-13) of almost cylindrical seeds per carpel. A. vanbruggenii has seeds almost as long as those of $A$. euryspermus but they are terete or flattened and about half as wide as the almost ovoid seeds of the latter.

Testa: the single or double seed coat or testa (Bouman 1985) is useful in many cases. Seeds with the distinct double testa are those of $A$. queenslandicus, A. lancesmithii, A. euryspermus, and A. vanbruggenii. A. queenslandicus has the outer layer tightly adhering to the inner coat, while the other three are quite loose and easily detached.

\section{Aponogeton}

Perennial freshwater herbs; monoclinous, monoecious or dioecious, with tuber or rhizome, stolon or corm and erect stem; entomophilous via beetles or bees, or cleistogamous; with milky sap and raised glands or punctae. Leaves simple, sheathing at base, alternate, petiolate or sessile, often containing hydropoten (localised regions of flat cells appearing as blotches), floating, floating and submersed, or all submersed; blades with parallel venation, main veins connected by cross veins, margins often bounded by a thin parallel vein; tissue between veins may disintegrate with age, leaving a network of veins separated by holes; axillary scales present. Inflorescence pedunculate, spadix subtended by a caducous or persistent spathe, branched or single, floating, projected above the water or remaining submerged. Flowers sessile, zygomorphic, perfect or imperfect; perianth in one whorl of 1-6 parts or absent, persistent, white to pink, yellow, green-blue or violet; stamens 6-18(-50), 2-loculed, dehiscing by longitudinal slits; carpels separate, 2-6(-9), superior, sessile, placentation basal. Fruit a follicle, with terminal, lateral, curved or straight beak. Seeds with straight embryo, lacking endosperm, with single or double testa. 


\section{Key to species}

1. Proliferous offshoots formed at tip of peduncle; plants rarely flowering

1. A. proliferus

$1^{*}$ Proliferous offshoots not formed on plants; plants regularly flowering ............... 2

2 . Inflorescence branched with two spikes ................................................................ 3

2* Inflorescence unbranched with one spike ........................................................... 5

3. Flowers white (rarely pink); tepals 1, with 13 or more veins ....... 2. A. distachyos

$3^{*}$ Flowers yellow, yellow-green, or green; tepals 2-6, 1-veined ................................ 4

4. Tepals 6; seeds (2.6-)5.1-6.2(-7.0) mm long; leaves all floating

3. A. hexatepalus

$4^{*}$ Tepals 2; seeds 2.1-3.2 mm long; leaves all submersed

4. A. lancesmithii

5. Leaves all submersed, slightly to strongly bullate 6

$5^{*}$ Leaves submersed and/or floating, not bullate .................................................... 7

6. Spathe persistent, to $2.5 \mathrm{~cm}$ long; inflorescence to $5.5 \mathrm{~cm}$ long; peduncle about same diameter as inflorescence rachis

5. A. bullosus

$6^{*}$ Spathe caducous, to $1.5 \mathrm{~cm}$ long; inflorescence to $34 \mathrm{~cm}$ long; peduncle much broader than inflorescence rachis

4. A. lancesmithii

7. Plants mainly producing floating leaves; floating blades mostly cordate at base; seeds with obvious double testa 6. A. queenslandicus

$7^{*}$ Plants mainly producing submersed leaves or submersed and floating leaves; floating blades mostly obtuse, some cuneate or truncate at base; seeds with a single testa or, if double, the second seed coat closely adhering and difficult to detect .. 8

8. Submersed leaves narrow, $0.9-3 \mathrm{~mm}$ wide; seeds $0.7-1.4 \mathrm{~mm}$ long

7. A. kimberleyensis

$8^{*}$ Submersed leaves broad, 5-60 mm wide; seeds 1.2-4.9 mm long 9

9. Fruit oval and thick-coated; seed coat closely adhering to embryo and difficult to detect, or tightly-fitting and very thin; floating leaves rarely formed

10. A. elongatus

9* Fruit elliptic and papery; seeds with a loose outer coat, easily separated from embryo; floating leaves commonly formed 10

10. Seeds broadly elliptic, nearly oval, (1.1-)1.5-2.8 mm wide 8. A. euryspermus $10^{*}$ Seeds narrowly elliptic, $0.7-1.6 \mathrm{~mm}$ wide 9. A. vanbruggenii 


\section{A. proliferus C.B. Hellquist \& S.W.L. Jacobs, sp. nov.}

A. elongato affinis, sed inflorescentiis raris, plerumque planta nova ad apicem pseudopedunculi spathacei substitutis, differt.

Holotype: Cultivated by Lance Smith, Townsville, K.L. Wilson 8747, 11 July 1994 (NSW). Isotype: BRI.

Rooted, submersed, perennial aquatic. Tubers small, less than $1 \mathrm{~cm}$; fibrous roots abundant. Leaves submersed; blades linear, $18.5-31 \mathrm{~cm}$ long, (0.4-)1.3-1.6 cm wide, dark green; margins flat to slightly undulate; base cuneate; apex obtuse to broadly mucronulate; 7-veined; lacunae 0 or 1 on each side of the midrib; petiole to $13 \mathrm{~cm}$ long. Peduncle to $32 \mathrm{~cm}$ long, broadening at base of inflorescence or proliferous offshoot. Spathe to $1.5 \mathrm{~cm}$ long, partially persistent. Inflorescence yellow, emergent, single, rarely formed, to c. $5.5 \mathrm{~cm}$ long; rachis c. $1.6 \mathrm{~mm}$ wide. Flowers widely spaced, mostly bisexual, few unisexual, staminate; flowers turned in all directions. Perianth segments 2, spathulate, 1-veined, yellow. Stamens (1-)4(-6); anthers c. $0.4 \mathrm{~mm}$ wide, $0.4 \mathrm{~mm}$ long, filaments c. $0.5 \mathrm{~mm}$. long, broader at base. Carpels (0-)4-5(-9). Fruit not seen. New plants commonly produced at tip of spathed peduncle-like structures.

Distribution: an extremely rare species now known only from the Innisfail region of Northern Queensland. Presumably now restricted because of extensive clearing and loss of habitat.

Specimens examined: Queensland: Innisfail district, creek through rainforest, S. Jacobs 7148 (NSW); cultivated at Kelso, Townsville by Lance Smith, S. Jacobs 8258, 17 Aug 1997 (NSW).

This species is named for the proliferous shoots produced; from the Latin prolifer.

Despite the proliferous shoots this species is difficult to propagate and the proliferous offshoots need to remain in contact with the parent plant until well established (L. Smith, pers. comm.). This is the only yellow-flowered taxon of two proliferous species known worldwide. The other is A. undulatus Roxb., a white-flowered species from Asia (Bruggen 1985). Only one plant of A. proliferus has been seen in flower and this was in cultivation. Its natural habitat seems to be narrow, shallow and heavily shaded coastal streams.

2. A. distachyos C. Linnaeus f., Suppl.: 215 (1781)

Holotype: LINN 479.3 p.p. (Bruggen 1973)

Rooted, submersed and floating, perennial aquatic. Tuber to $6 \mathrm{~cm}$ long. Leaves floating, blades ovate, narrowly elliptic, or narrowly lanceolate, $6-26(-32.5) \mathrm{cm}$ long, 1.5-7.5 $(-8.6) \mathrm{cm}$ wide; margins flat; base mostly obtuse or attenuate; apex obtuse, acute, or acuminate, 7-9-veined; petiole to $100 \mathrm{~cm}$ long. Peduncle to $80 \mathrm{~cm}$ long, often broadening at base of inflorescence. Spathe c. $3 \mathrm{~cm}$ long, caducous. Inflorescence branched with two spikes to $5.5 \mathrm{~cm}$ long. Flowers secund, in 2 rows. Perianth segments 1, white or pinkish, \pm 13 -veined, $10-15(-30) \mathrm{mm}$ long, $3.5-12 \mathrm{~mm}$ wide. Stamens 8-16, 3-4.5 mm long, anthers purplish black, filaments wider at base. Carpels 2-6. Infructescence to $7 \mathrm{~cm}$ long. Fruit to $22 \mathrm{~mm}$ long, $6 \mathrm{~mm}$ wide, with a curved or straight terminal beak to $5 \mathrm{~mm}$ long. Seeds to $18 \mathrm{~mm}$ long, $7 \mathrm{~mm}$ wide, with a single loose testa and small embryo.

Distribution: naturalised in southern South Australia, southern New South Wales, and Victoria. This is the only introduced species of Aponogeton naturalised in Australia. It is sometimes regarded as a minor weed though it is widely planted as an ornamental in temperate areas because it is one of the few aquatic species that flowers in the cooler months. 
Selected specimens examined: South Australia: Mount Lofty Range. Mylor, c. $20 \mathrm{~km}$ south-east of Adelaide, N.N. Donner 97, 2 July 1961 (MEL). New South Wales: Vineyard Creek, Rydalmere, $33^{\circ} 49^{\prime} \mathrm{S}, 151^{\circ} 02^{\prime}$ R.G. Coveny 6142, D. Benson, L. Johnson \& K. Wilson, (NSW); Royal Botanic Gardens, Sydney, S. Jacobs 3345, 1 May 1978 (NSW). Victoria: c. 6 miles [9 km] south-east of Traralgon, A. Eddy s.n., 29 May 1965 (MEL); Gisborne, in Jacksons Creek, where crossed by the Calder Highway, H.I. Aston 1144 (MEL); Lorne, Stony Creek, at crossing of the Great Ocean Road just immediately north of the town, H.I. Aston 1585 (MEL); Lilydale district, approx. $35 \mathrm{~km}$ from Melbourne city center, H.T. Clifford s.n., Oct 1948 (MEL); 1 mile [1.3 km] west of Ferntree gully, Ferny Creek at the crossing of the road to Lysterfield, just as it leaves the main Melbourne-Ferntree Gully road, H.I. Aston 918, 21 Feb 1963 (MEL, NSW); Mornington Peninsula, north of Bewtons Rd, $1 \mathrm{~km}$ east of its junction with Moorooduc Rd, Bill Peel 51, 5 Sep 1981 (MEL); Otway Ranges, c. 18 miles [25 km] south-west of Colac, c. $1 \frac{1}{2}$ miles [3 km] west of Carlisle, in the Gellibrand River, H.I. Aston 1595 (MEL); south-eastern Otways, c. 9 miles [12 km] direct line north-east of Apollo Bay, Great Ocean Road, c. $1 \frac{1}{2}$ mile [1 km] east of Carisbrook Creek, H.I. Aston 1590, 22 March 1967 (MEL); Allsops Creek, $2 \mathrm{~km}$ from old Jeetho railway station; approx. $8 \mathrm{~km} \mathrm{NW}$ of Kurumburra, J. Scott s.n., 1 Oct 1980 (MEL); West Macedon, A.J. Tadgell s.n., 1 May 1932 (MEL).

Grows in slow-flowing freshwater creeks and rivers, lakes, and garden ponds. Flowers and fruits from September to May. This species grows best in the cooler waters and during the cooler times of the year, hence is often most productive in spring and autumn. This is widely planted as an ornamental water garden plant and is commonly known as the Water Hawthorn, Cape Hawthorn or Cape Pondweed. Native to southern South Africa.

\section{A. hexatepalus H. Bruggen, Blumea 17: 136 (1969)}

Holotype: Western Australia: Trigwell, den Hartog 203, 26 Aug 1967 (L). Isotype: L.

Rooted, submerged and floating, perennial aquatic. Tubers elongate to $6.5 \mathrm{~cm}$ long, $2 \mathrm{~cm}$ wide. Leaves floating, narrowly oblong, to $20 \mathrm{~cm}$ long, $0.3-0.7 \mathrm{~cm}$ wide, margins flat; base narrowly cuneate; apex obtuse or blunt-cuneate; 5-9-veined, some indistinct; petiole to $20 \mathrm{~cm}$ long. Peduncle to $40 \mathrm{~cm}$ long, not broadened or inflated at base of inflorescence. Spathe $2-3 \mathrm{~cm}$ long, persistent. Inflorescence branched forming 2 spikes, green (yellowish-green), to $17 \mathrm{~cm}$ long, laxly-flowered, sometimes further branching present; rachis white, lower portion bare. Flowers turned in all directions. Perianth segments 6, transverse broadly obovate, 1-veined, green. $0.5-1 \mathrm{~mm}$ long, $0.75-1.25 \mathrm{~mm}$ wide. Stamens 6; anthers $0.3 \mathrm{~mm}$ long, $0.3 \mathrm{~mm}$ wide; filaments to $1.5 \mathrm{~mm}$ long, slightly broader at base. Carpels 3(-4). Fruit (3.8-)5.0-7.0(-10.0) mm long, 1.9-3.2(-5.0) mm wide, with a terminal beak. Seeds elliptic, (2.6-)5.1-6.2(-7.0) $\mathrm{mm}$ long, (1.2-)1.7-3.0 mm wide, with a single testa, plumule present.

Distribution: endemic to southwest Western Australia in the vicinity of Perth. Now rare due to loss of habitat.

Selected specimens examined: Western Australia: Kenwick, south of Perth, 32 ${ }^{\circ}$ '55"S, $115^{\circ} 58^{\prime} 09^{\prime \prime} \mathrm{E}$, S. Jacobs 6947, 16 Nov 1993 (NSW), G. Sainty 1890, 10 Oct 1993 (NSW); old school site, Waterloo, NNE of Bunbury, 33¹9'51"S, 11545'27"E, S. Jacobs, 15 Nov 1993 (NSW).

Grows in freshwater ephemeral pools that contain water for 3 to 4 months a year. Flowering and fruiting from August to November. This is the only species of Aponogeton that consistently has 6 perianth segments.

\section{A. lancesmithii C.B. Hellquist $\mathcal{E}$ S.W.L. Jacobs, sp. nov.}

A. elongato A. bullosoque affinis; ab A. elongato foliis plus minusve bullosis differt; ab $A$. bulloso spatha inflorescentiae caduco, inflorescentia plerumque emergenti, differt; a speciebus ambobus testis duabus seminium, testa exteriori longitudinaliter plicata porcatave differt. 
Holotype: Queensland: Woopen Creek at crossing $7 \mathrm{~km}$ west of Russell River bridge along Woopen Creek Road, SW of Babinda, C.B. Hellquist 16197, C.E. Hellquist $\mathcal{E}$ L. Smith, 6 Oct 1997 (NSW). Isotypes: B, BRI, GH, MEL, NASC, US, Z.

Rooted, submerged, perennial aquatic. Tuber ovate-elongate, to $5 \mathrm{~cm}$ long, $2-3 \mathrm{~cm}$ wide. Leaves submersed; blades linear-lanceolate, $10-48 \mathrm{~cm}$ long $0.9-4 \mathrm{~cm}$ wide, slightly to strongly bullate, green to dark green; margins slightly undulate; base narrowly cuneate; apex obtuse or narrowly blunt-cuneate; 7-9-nerved; 0-2 rows of lacunae on each side of midvein; petiole to $36 \mathrm{~cm}$ long. Peduncle to $74 \mathrm{~cm}$ long, 1.2-1.8 $\mathrm{mm}$ wide at base, broadening to $4.2-6.8 \mathrm{~mm}$ at base of inflorescence. Spathe $0.9-1.5 \mathrm{~cm}$ long, $0.7-0.9 \mathrm{~cm}$ wide, caducous. Inflorescence yellow, often floating on surface with the tip emergent, single, rarely branched, to c. $34 \mathrm{~cm}$ long, sparsely to tightly flowered; rachis 1.5-4.5 mm wide. Flowers turned in all directions. Perianth segments 2, spathulate, 1-veined, yellow, 1.5-1.7 mm long, 0.8-1.3 mm wide. Stamens (4-)6(-8); filaments c. $1.5 \mathrm{~mm}$ long, broader at base. Carpels (2-)3-5(-7). Infructescence dense. Fruit 3-3.9 mm long, 2.7-3.5 mm wide, with a somewhat straight or bent terminal beak. Seeds 3-8 per fruit, $2.1-3.2 \mathrm{~mm}$ long, $0.6-1.0 \mathrm{~mm}$ wide, with double testa and loose coat with longitudinal folds.

Distribution: endemic to the Russell River and its tributaries in the Innisfail District of Far Northern Queensland. Grows in slow-to fast-flowing rivers.

Selected specimens examined: Queensland: Russell River, W.G. Trapnell 109, 110, 3 July 1960 (BRI); Russell River-Bruce Highway, W. Irvine, s.n., 26 Aug 1986 (NSW); S. Jacobs 724014 Nov 1994 (NSW); S. Jacobs, 8248, B. Hellquist, E J. Wiersema, 14 Aug 1997 (BRI, NASC, NSW); Stone Creek north of Innisfail, $17^{\circ} 29.01^{\prime} \mathrm{S}, 146^{\circ} 00.97^{\prime} \mathrm{E}, \mathrm{S}$. Jacobs 7153 (NSW); Woopen Creek, a small tributary of Russell River 8 miles [12 km] S of Babinda, $1^{\circ} 27^{\prime} \mathrm{S}, 145^{\circ} 55^{\prime} \mathrm{E}$, K. Williams 216, 16 Oct 1968 (BRI); Woopen Creek, a tributary of the Russell River, approximately $16 \mathrm{~km}$ SSE of Babinda, G. Trapnell, s.n., July 1970 (BRI).

Grows in slow- to fast-flowing waters of streams. Flowers and Fruits from at least July to November.

This species is named for Lance Smith, an aquatic plant propagator and grower from Kelso (Townsville), Queensland who has been instrumental in propagating and preserving a number of species of Aponogeton and providing us with critical specimens and information.

Bruggen (1969) included the limited material of this species that he was able to examine in A. bullosus.

Unlike $A$. bullosus, which produces fairly short peduncles and mostly submerged inflorescences, $A$. lancesmithii produces very long inflorescences on inflated peduncles that are longer than any other species in Australia. The inflorescences are usually emergent. The leaves are often bullate. This character at first led us to believe that it was a possible hybrid between $A$. elongatus and $A$. bullosus. However, the seeds of A. lancesmithii are more similar to those of $A$. queenslandicus, $A$. vanbruggenii, and A. euryspermus than to those of either A. elongatus and A. bullosus. A. lancesmithii seeds have a double testa and a loose outer coat but they are generally smaller than the seeds of $A$. vanbruggenii and $A$. macrospermus.

\section{A. bullosus H. Bruggen, Blumea 17: (1939)}

Holotype: Queensland: Ravenshoe, Millstream River, den Hartog 1049, 15 Nov 1967 (L). Isotype: L.

Rooted, submerged, perennial aquatic. Tubers elongate to $2 \mathrm{~cm}$ long. Leaves submersed; blades linear to linear-lanceolate, 7-40(-50) cm long, $(0.5-) 1-2(-2.5) \mathrm{cm}$ wide, strongly bullate, dark green; margins undulate; base narrowly cuneate; apex 
blunt-cuneate to obtuse, 3-5(-7)-veined; lacunae 0-2 rows on either side of midvein; petiole $1-10(-18) \mathrm{cm}$ long. Peduncle to $30 \mathrm{~cm}$ long, not noticeably thicker at base of inflorescence. Spathe to $2.5 \mathrm{~cm}$ long, mostly persistent. Inflorescence yellow, single to $5.5 \mathrm{~cm}$ long, mostly remaining submerged. Flowers turned in all directions. Perianth segments 2, spathulate or obovate, 1-veined, yellow, 0.75-2.7 mm long, 0.75-1.5 mm wide. Stamens 6, filaments 1.2-1.6 mm long, slightly broader at base. Carpels (2-)3-5. Infructescense dense, cone-shaped, usually submersed. Fruit 4.2-6 mm long, 3-4 mm wide, with a terminal beak. Seeds 3-8 per fruit, 2.2-2.5 mm long, 1-1.6 mm wide, with a simple testa. Embryo without plumule.

Distribution: confined to northern Queensland in fast-flowing rivers on and running off the Atherton Tableland. The fruit consistently develop below the water surface. Emergent flowers are not commonly seen.

Selected specimens examined: Queensland: Calleja Bridge, South Johnstone R., $17^{\circ} 35.62^{\prime} \mathrm{S}$, 14557.17'E, S. Jacobs 7147, 2 July 1996 (NSW); Cochable Creek, Forestry Reserve 756, B. Hyland APO/2775 June 1962 (BRI); Five Mile Creek, 17²5'S, 14540'E, A.W. Dockrill 1176, 20 June 1976 (BRI); Malanda, North Johnstone River, B. Chirping 9674, 20 Sept 1945 (MEL); North Johnstone R., Jaggon-Butchers Creek road, $17^{\circ} 22.38^{\prime} \mathrm{S}, 145^{\circ} 37.98^{\prime} \mathrm{E}, \mathrm{S}$. Jacobs 8253 , B. Hellquist $\mathcal{E}$ J. Wiersema, 15 Aug 1997 (BRI, NASC, NSW); tributary of N. Johnstone R., Jaggon-Butchers Creek road, $1^{\circ} 23.56$ 'S, $145^{\circ} 37.31^{\prime} \mathrm{E}$, S. Jacobs 8252, B. Hellquist \& J. Wiersema, 15 Aug 1997 (BRI, NSW); National Park 226, Palmerston Section, Henrietta Creek, near camping area, P.D. Bostock 1572, July 1994 (BRI); Theresa Creek, Millaa Millaa, W.G. Trapnell 251, 17 June 1960 (BRI); The Millstream, Ravenshoe, $17^{\circ} 38^{\prime} \mathrm{S}, 145^{\circ} 29^{\prime} \mathrm{E}$, S. Jacobs 4782 \& G. Sainty (NSW); Josephine Creek, Bartle Frere to highway road, 17²5.82'S, 14553.93'E, S. Jacobs 8249, B.Hellquist, J.Wiersema, 14 Aug 1997 (BRI, NASC, NSW).

Grows in cool rapidly flowing freshwater rivers and streams. Flowers and fruits from June to October.

The flowers sometimes emerge for a very short time above the surface for pollination and fall below the surface to develop fruit. When the flowers do not emerge they still produce fruit. The infructescence is typically quite short, and conical with usually all fruit developed. The distinguishing characteristic of this species is the extremely bullate leaves. This species retains the spathe longer than any other Australian species of Aponogeton.

\section{A. queenslandicus $H$. Bruggen, Blumea 17: 123-125 (1969)}

Holotype: Rockhampton, Thozet s.n. (MEL). Isotype: MEL.

Rooted, submerged and floating, perennial aquatic. Tubers 1-5 cm long, $1.8-2.6 \mathrm{~cm}$ wide, extremely strigose. Leaves submersed and floating; submersed blades uncommon, elliptic to lanceolate, green, $10-13(-70) \mathrm{cm}$ long, $2.9-4.5 \mathrm{~cm}$ wide; margins flat; base obtuse, attenuate, or truncate; apex obtuse; 7-9-veined; 0-1 row of lacunae on each side of midvein; petiole to $15 \mathrm{~cm}$ long. Floating leaves ovate or elliptic, $2.8-14(-27) \mathrm{cm}$ long, $0.6-4.3 \mathrm{~cm}$ wide; light green to green, base mostly cordate, rarely truncate or cuneate; apex obtuse, mucronulate, acuminate, rarely emarginate; 7-9veined; petiole to $66 \mathrm{~cm}$ long. Peduncle to $30(-73) \mathrm{cm}$ long; $1.8-2.5 \mathrm{~mm}$ wide at base often only slightly broadening or to $2-4.5 \mathrm{~mm}$ wide at base of inflorescence. Spathe to $1.5 \mathrm{~cm}$ long, caducous. Inflorescence yellow, emergent or floating, single, usually tightly-flowered; rachis $15-27(-45) \mathrm{mm}$ wide. Flowers turned in all directions. Perianth segments 2, spathulate, 1-veined, 1.4-2 mm long, 0.5-1 mm wide. Stamens 6, up to $3 \mathrm{~mm}$ long, slightly broader at base. Carpels (2-)3(-4). Infructescence dense. Fruit $2.5-4.5 \mathrm{~mm}$ long, $2.3-3 \mathrm{~mm}$ wide, with a terminal, often curved, beak. Seeds narrowly elliptic, 4-13 per fruit, 1.7-3 mm long, 0.6-1 mm wide, with a double testa; outer testa loose, transparent and reticulate, inner testa brown and close fitting; plumule absent. 
Distribution: northeast Northern Territory and throughout Queensland south of Cape York Peninsula, though more common west of the Great Divide and not common in the driest areas.

Selected specimens examined: Northern Territory: $11 \mathrm{~km}$ from Borroloola, Daly Waters Road,


Eucalyptus forest, S.T. Blake 18562, 29 Sept 1950 (BRI); Gilruth Plains, Cunnamulla, 190 m, H.S. McKee 10350, 12 April 1963 (BRI); Dorunda Lake overflow, $1 \mathrm{~km}$ north of Dorunda homestead, 16 32'S, 141 49'E, V.J. Neldner 2926 \& J.R. Clarkson, 12 June 1990 (BRI, MEL, NSW,); Dalrymple Shire, Fletcher Creek near junction with Burdekin River, K.A. Williams 81081, 8 July 1981 (BRI); c. 10 km $\mathrm{N}$ of the Gums, Condamine road, 27²14.63'S, 150¹0.64'E, S. Jacobs 8356 \& B. Hellquist, 28 Nov 1997 (BRI, NASC, NSW); 63 km SE of Home Hill, Bruce Hwy, 1955' S, 147 50’ E, S. Jacobs 408616 May 1981 (NSW); $2.8 \mathrm{~km}$ from Kowanyama on the road to Shelfa Crossing, $15^{\circ} 28^{\prime} \mathrm{S}, 141^{\circ} 45^{\prime} \mathrm{E}$, J.R. Clarkson 9574 \& V.J. Neldner, 26 May 1992 (BRI); c. 24 km N of Mareeba, Mt Molloy Road, $16^{\circ} 45^{\prime}$ S, $145^{\circ} 20^{\prime} \mathrm{E}$, S. Jacobs 4848 \& G. Sainty, 1 May 1986 (MEL, NSW); 'Myall Park', Crater

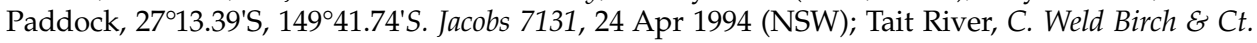
Zelling s.n, 1892 (MEL); Fitzroy River Basin Brigalow Research Station, 20 miles [32 km] NW of Theodore, R.W. Johnson 2619, 24 Apr, 1963 (BRI).

Grows in freshwater ephemeral habitats in drier regions, particularly gilgais in Brigalow scrub, melon-holes, ponds, and roadside ditches. Flowers and fruits in response to water levels and temperature, but more commonly during the warmer months.

Aponogeton queenslandicus occasionally produces submersed leaves.

A population of $A$. vanbruggenii on the Atherton Tableland resembles A. queenslandicus in producing almost all cordate-based floating leaves, but when the seeds are examined it is clearly the former species.

7. A. kimberleyensis C.B. Hellquist \& S.W.L. Jacobs, sp. nov.

A. euryspermo affinis, sed foliis submersis multo angustioribus, seminibus multo minoribus, differt.

Holotype: Western Australia: water supply at Kuri Bay, 15²9'17'S, 124²9'54"E, A.A. Mitchell 3501, 21 March 1994 (NSW). Isotype: Agriculture Broome.

Rooted, submerged, perennial aquatic. Leaves submersed; blades linear, rarely slightly broadened, 24-32 cm long, 0.09-0.3 cm wide; dark green; margins flat; base longtapered, almost parallel-sided; apex obtuse to rarely retuse; 5-veined; lacunae band prominent, to $2 \mathrm{~mm}$ wide, with up to 4 rows on each side of the midvein; petiole c. $5 \mathrm{~cm}$ long. Peduncle to $32 \mathrm{~cm}$ long, $0.4-1 \mathrm{~mm}$ wide at base, broadening to $0.5-2.4 \mathrm{~mm}$ wide at base of inflorescence. Spathe not seen. Inflorescence yellow, emergent, single, to $7.5 \mathrm{~cm}$ long; rachis $0.5-2 \mathrm{~mm}$ wide. Flowers turned in all directions. Perianth segments 2, spathulate, 1-veined, yellow, 1-1.4 mm long, $0.8 \mathrm{~mm}$ wide. Stamens 6; anthers c. $0.2 \mathrm{~mm}$ long, $0.2 \mathrm{~mm}$ wide; filaments $1-1.5 \mathrm{~mm}$ long, broader at base. Carpels 3 . Infructescence slightly spaced along axis. Fruit $2.5-3.0 \mathrm{~mm}$ long, $2.0-2.8 \mathrm{~mm}$ wide, with an erect to slightly curved terminal beak. Seeds (1-)2-3 per fruit, $0.7-1.4 \mathrm{~mm}$ long, $0.4-0.8 \mathrm{~mm}$ wide; single testa with tight coat and fine reticulations.

Distribution: endemic to the western Kimberley of Western Australia.

Specimen examined: Western Australia: Langey, West Kimberley, $15^{\circ} 50^{\prime} S, 1^{\circ} 4^{\circ} 23^{\prime} \mathrm{E}, \mathrm{G}$. Sainty s.n., 25 May 1991 (NSW).

Known only from streams. Flowering and fruiting specimens from March and May.

This species is named for the Kimberley region of northwest Western Australia where it grows. 
8. A. euryspermus C.B. Hellquist $\mathcal{E}$ S.W.L. Jacobs, sp. nov.

A. elongato affinis, sed seminibus multo majoribus, foliis interdum natantibus, differt.

Holotype: Western Australia: King Edward River Crossing, Mitchell Plateau Road, $14^{\circ} 54.07^{\prime} \mathrm{S}, 126^{\circ} 12.01$ 'E, S. Jacobs 8030, 18 May 1996 (NSW). Isotypes: NASC, PERTH, Z.

Aponogeton elongatus forma strigosus H. Bruggen, Blumea 17: 133 (1969).

Holotype: Northern Territory: Edith Falls Road., c. 3 miles [5 km] E of Stuart Highway, L.G. Adams 1658 (L). Isotype: NSW.

Rooted, submersed perennial aquatic. Tuber ovate-elongate, to $1-3 \mathrm{~cm}$ long, $1-2 \mathrm{~cm}$ wide. Leaves submersed and/or floating. Submersed blades linear, linear-lanceolate, ovate, or elliptic, to $23(-35) \mathrm{cm}$ long, (0.5-)1.4-2.5(-6) cm wide; margins flat or slightly undulate; base narrowly to broadly cuneate, obtuse, or attenuate; apex obtuse, broadly obtuse, blunt-cuneate to acute-cuneate, truncate, or rarely retuse; (3-)7-9(-11)-veined; $1-5$ rows of lacunae on each side of midvein; petiole to $23(-50) \mathrm{cm}$ long. Floating leaves ovate or elliptic, to $11 \mathrm{~cm}$ long, green to maroon-green; margins flat; base cuneate, obtuse, or attenuate; apex obtuse; midrib with 2-4 parallel veins on both sides; petiole to $64 \mathrm{~cm}$ long. Peduncle to $29(-107) \mathrm{cm}$ long, $0.6-1.8 \mathrm{~mm}$ wide at base broadening to (0.7-)2.2-4.8 mm wide at base of inflorescence. Spathe to $1.5 \mathrm{~cm}$ long, caducous. Inflorescence yellow, emergent or floating, single, rarely branched, to c. $17 \mathrm{~cm}$ long, tightly flowered or spread out along rachis; rachis $0.9-3 \mathrm{~mm}$ wide. Flowers turned in all directions. Perianth segments 2, spathulate, 1-veined, yellow, 1.1-2 mm long, 0.7-1.5 mm wide. Stamens 6; anthers c. $0.2-0.5 \mathrm{~mm}$ long, $0.4-0.5 \mathrm{~mm}$ wide; filaments 1.2-2.1 mm, broader at base. Carpels (2-)3. Infructescence moderately dense. Fruit 3-6.2 mm long, 2.4-5 mm wide, beak to $1 \mathrm{~mm}$ long, terminal or lateral, reflexed or straight. Seeds broadly elliptic, almost ovoid, 1-5 per fruit, usually 1 per small fruit, 2.3-4.9 mm long, (1.1-)1.5-2.8 mm wide, thick outer testa easily removed, a second, if present, tightly adhering and difficult to remove.

Distribution: northern portion of Western Australia from the Kimberley east to the northern portion of the Northern Territory and Arnhem Land.

Selected specimens examined: Western Australia: Adcock Gorge, $16^{\circ} 56^{\prime} \mathrm{S}, 125^{\circ} 48^{\prime} \mathrm{E}, \mathrm{S}$. Jacobs 4388 , 3 June 1982 (NSW); c. 3 km W of 'Ellenbrae' turnoff, Gibb River road, $15^{\circ} 59.47^{\prime} \mathrm{S}, 127^{\circ} 01.30^{\prime} \mathrm{E}$, S. Jacobs 8015, 17 May 1996 (NSW); feeder stream of the Drysdale River, 49 km north-west of 'Mt Elizabeth' station, on track to Bachsten Creek, W.M. Molyneux \& S.G. Forrester s.n., 30 June 1987 (MEL); 'Texas Downs' station, E of Mount John, K.A. Menkhorst 622, 28 July 1989 (DNA); c. 13 km SE of 'Kimbolton' Hotel, 'Oobagooma' road 16 ${ }^{\circ} 44^{\prime} \mathrm{S}, 123^{\circ} 54^{\prime} \mathrm{E}$, S. Jacobs 5742, 26 May, 1988 (NSW); Yampi Peninsula, in Trent River Gorge, $16^{\circ} 37^{\prime}$ S, $123^{\circ} 42.5^{\prime}$ E, P.A. Fryxell, L.A. Craven E J. McD. Stewart 4574, 31 May 1985 (MEL); $500 \mathrm{~m}$ west of Moochalabra Dam, $35 \mathrm{~km}$ south of Wyndham, $15^{\circ} 37^{\prime} 45^{\prime \prime S}, 128^{\circ} 05^{\prime} 05^{\prime \prime E}$, A.A. Mitchell 3699, 27 July 1994 (NSW). Northern Territory: Arnhemland, Mt Gilruth area, $13^{\circ} 03^{\prime} \mathrm{S}, 133^{\circ} 01^{\prime} \mathrm{E}$, T.S. Henshall 1869, 6 June 1978 (DNA, MEL); lagoon at Jabiru, $12^{\circ} 40^{\prime} \mathrm{S}, 132^{\circ} 53^{\prime} \mathrm{E}$, L.A. Craven 2277, 17 Feb 1973 (DNA, MEL); Kakadu Nat. Park, 1332'S, 132²9'E, J. Russell-Smith 8559, 7 Jan 1992 (DNA).

Grows in freshwater streams, rivers and lagoons. Flowering and fruiting December to February and May to July.

This species is named for the large broad seed produced; from the Greek eurys, broad and spermus, seed.

Many specimens of Aponogeton from the tropics were originally assigned to A. elongatus by Bruggen (1985) and others. These specimens represent taxa that initially produce submerged leaves in flowing or clear water. Later in the year plants that we assign to either A. euryspermus or A. vanbruggenii often develop floating leaves. These species may be separated by seed shape and size; $A$. euryspermus has large broad seeds that can become very thick when mature while $A$. vanbruggenii has longer and narrower 
seeds with a distinct knob at one end. Both have seeds with a thin outer testa that is easily removed. Both species are confined to the tropics with $A$. euryspermus more westerly in its distribution and A. vanbruggenii more easterly.

\section{A. vanbruggenii C.B. Hellquist $\mathcal{E}$ S.W.L. Jacobs sp. nov.}

A. elongato affinis, sed seminibus plerumque complanatis, testis duabus, foliis interdum natantibus, differt.

Holotype: Queensland: McIvor River, 'Battle Camp' road, 1507'13"S, 145 04'47'E, S. Jacobs 8198, B. Hellquist \& J. Wiersema (NSW). Isotypes: BRI, NASC, Z.

Rooted submersed perennial aquatic. Tuber ovate to elongate, to $0.5-4 \mathrm{~cm}$ long, $0.5-2.5 \mathrm{~cm}$ wide. Leaves submerged and/or floating. Submersed blades lanceolate, elliptic, or obovate, 7-36 cm long, $0.6-5 \mathrm{~cm}$ wide, green to maroon-green; margins slightly to strongly undulate, rarely flat; base broadly cuneate, obtuse, rarely truncate; apex obtuse to blunt-cuneate, 5-9(-11)-veined; 0-2(-4) rows of lacunae on each side of the midvein; petiole to $15(-23) \mathrm{cm}$ long. Floating leaves elliptic or ovate to $12(-38) \mathrm{cm}$ long, $0.7-2.5(-5) \mathrm{cm}$ wide, green to maroon-green; margins flat; base cuneate, obtuse, attenuate, or truncate, rarely cordate; apex blunt-cuneate, obtuse, mucronulate, rarely cuspidate; 5-9 veined; petiole to $91 \mathrm{~cm}$ long. Peduncle to $50(-80) \mathrm{cm}$ long, broadening to $1.0-2.8(-4.2) \mathrm{mm}$ wide at the base of inflorescence. Spathe to $1.5 \mathrm{~cm}$ long, caducous. Inflorescence yellow, emergent or floating, single, tightly flowered to widely spaced along rachis; rachis 1.1-3.2 mm wide. Flowers turned in all directions. Infructescence moderately dense to spread out along rachis. Perianth segments 2, spathulate, rarely obovate, 1-veined, yellow, 1.2-2.1 mm long, 0.7-1.5 mm wide. Stamens 6; anthers c. $0.2-0.6 \mathrm{~mm}$ long, $0.2-0.6 \mathrm{~mm}$ wide; filaments $1-2.5 \mathrm{~mm}$ long, broader at base. Carpels (2-)3(-5). Fruit elliptic, thin and papery; (2.7-)3.4-7.1 mm long, 2.2-4.5(-5.5) $\mathrm{mm}$ wide, beak to $1 \mathrm{~mm}$, mostly terminal, straight, bent, or reflexed, occasionally lateral. Seeds obovate or narrowly elliptic (2-)3-5(-7) per fruit, 2.3-4.8 mm long, 0.7-1.6 $\mathrm{mm}$ wide, distinctly flattened or terete with a distinct knob at one end, with two testas; outer testa loose and easily removed, inner testa usually easily removed.

Distribution: eastern tropical Northern Territory and Queensland.

Selected specimens examined: Northern Territory: Eastern Arnhem Land, Bralminar, $12^{\circ} 32^{\prime} \mathrm{S}$, $135^{\circ} 55^{\prime} \mathrm{E}$, J. Russell-Smith 8920, 28 Sept 1992 (DNA); Calvert River Gorge, 1653'S, 137²2'E, P.K. Latz 10378, 30 Sept 1986 (DNA, MEL); 'Elsey' station, Roper River, $14^{\circ} 27^{\prime S}, 1^{\circ} 3^{\circ} 22^{\prime} \mathrm{E}$, T.S. Henshall 2025, 19 June 1978 (DNA, MEL); King River at Victoria Highway Crossing, $14^{\circ} 42^{\prime}$ S, $132^{\circ} 05^{\prime}$ E, T.S. Henshall 3547, 29 March 1981 (DNA, MEL); 30 km E Mataranka, Jilkmingan area, 14º5'S, $133^{\circ} 26^{\prime} \mathrm{E}$, Wightman 4933 \& D.R.L., 2 July 1990 (DNA).

Queensland: tributary of Gordon Creek, a tributary of Claudie River, $12^{\circ} 45^{\prime} \mathrm{S}, 143^{\circ} 15^{\prime} \mathrm{E}$, A.W. Dockrill

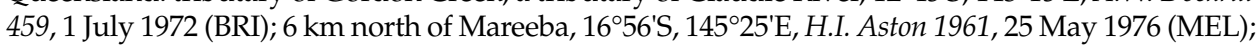
c. $16 \mathrm{~km} \mathrm{~S}$ of Mt Molloy, Mareeba road, $16^{\circ} 47.66^{\prime} \mathrm{S}, 145^{\circ} 21.49^{\prime} \mathrm{E}, \mathrm{S}$. Jacobs 8244 , B. Hellquist $\mathcal{E}$ J. Wiersema, 13 Aug 1997 (BRI, NASC, NSW); Pascoe River, 12³0'S, 143¹6'E, AIM 635, 13 Aug 1979 (BRI); Port Douglas, Mowbray River c. $1 \mathrm{~km} \mathrm{~S}$ of Port Douglas turnoff, $2.2 \mathrm{~km} \mathrm{~W}$ of Port Douglas-Cairns Highway, C.B. Hellquist 16194, C.E. Hellquist, L. Smith E E. Frye, 6 Oct 1997 (BRI, NASC, NSW).

Grows in freshwater rivers, streams, still-water portions of lakes, and billabongs. Flowers and fruits recorded from March to October and January.

This species is named to honour H.W.E. van Bruggen, the recognised world expert on the genus Aponogeton.

A. vanbruggenii superficially resembles $A$. euryspermus (see discussion above) but differs from that species in having smaller and narrower seed with a distinct knob at one end. A. vanbruggenii, like A. euryspermus, also may regularly produce floating 
leaves in still or turbid waters, especially late in the season. A few populations of A. vanbruggenii appear very similar to A. queenslandicus, with mainly floating leaves, but the two species are easily distinguished by the seeds.

10. A. elongatus F. Muell. ex Bentham, Fl. Austr. 7: 188 (1878)

Holotype: Queensland: Brisbane River, F. Mueller s.n., Dec 1856 (K).

Submersed aquatic perennial. Tuber ovate to elongate, to $4 \mathrm{~cm}$ long, $1.5 \mathrm{~cm}$ wide. Leaves submersed and rarely floating (except for subsp. fluitans); submersed blades narrow to broadly-elliptic to elongate, 7-34(-42) cm long, 0.8-3.7(-6.7) cm wide, green or dark green to maroon-green; margins slightly undulate to undulate; base broadly cuneate, obtuse, or rarely truncate; apex blunt-cuneate or obtuse; (5-)7-9(-11)-veined; $0-2(-4)$ rows of lacunae on each side of the midrib; petiole to $17(-35) \mathrm{cm}$ long. Floating leaves not commonly formed, narrowly elliptic to slightly obovate, 9-19 cm long, 2.2-3.5 cm wide; base obtuse, broadly cuneate, cordate, or truncate; apex obtuse; 7-9veined; petiole to $60(-90) \mathrm{cm}$ long. Peduncle to c. $90 \mathrm{~cm}$ long, $0.6-0.8 \mathrm{~mm}$ wide at base broadening to $1.0-2.8(-4.2) \mathrm{mm}$ wide at base of inflorescence. Spathe to $1.5 \mathrm{~cm}$ long, caducous. Inflorescence yellow, emergent or floating, single, tightly-flowered or spaced along the rachis; rachis 1.1-3.1 mm wide. Flowers turned in all directions. Perianth segments 2, spathulate, 1-veined, yellow, 1-2(-2.7) mm long, 0.7-1.2 mm wide. Stamens 6; anthers $0.3-0.4 \mathrm{~mm}$ long, $0.3-0.6 \mathrm{~mm}$ wide; filaments $0.8-1.7(-2.7) \mathrm{mm}$ long, broader at base. Carpels (2-)3(-6). Fruit rounded, thick-coated, 2.5-5.8 mm long, $1.8-5.0 \mathrm{~mm}$ wide; beak mostly lateral, occasionally terminal, to $1.5 \mathrm{~mm}$ long. Seeds $2-5$ per fruit, 1.2-3.2(-4.2) mm long, 0.5-1.1(-1.6) mm wide, elliptic, with a single testa, closely adhering to embryo or very thin.

1. Plants rarely or never producing floating leaves 10a. subsp. elongatus

1* Plants commonly producing floating leaves 10b. subsp. fluitans

\section{0a. A. elongatus subsp. elongatus}

As for species description except that floating leaves are rarely formed.

A. elongatus forma longifolius Bruggen, Blumea 17: 10-11 (1969).

Distribution: coastal Queensland and coastal northeastern New South Wales.

Selected specimens examined: Queensland: Sheep Station Creek, Kilcoy, G. Trapnell s.n., 6 Feb 1957 (BRI); Portland Roads Road between Tozers Gap and the Middle Claudie Crossing, J.R. Clarkson 2923, 25 Feb 1980 (DNA, MEL); S arm of Maroochy River, W.G. Trapnell s.n., 20 Mar 1960 (BRI); Yandina, J.H. Simmonds s.n., 1 Mar 1891 (BRI). New South Wales: Orara River, Coramba, J.S. Boorman s.n., Nov 1912 (NSW); Nana Glen, Orara River, 3008.01'S, 15300.50'E, S. Jacobs 8346, B. Hellquist, E. Bagley, 25 Nov 1997 (NASC, NSW); S of Lismore, S. Jacobs, 8354 E B. Hellquist, 27 Nov 1997 (NASC, NSW); Grafton, Miss Thornton s.n., (MEL 18784); Richmond River, Rudder s.n., Aug 1885 (NSW); Tintenbar, W. Baeuerlen, s.n., Oct 1894 (NSW).

Grows in freshwater portion of coastal rivers and streams. Flowers and fruits from October to March.

10b. A. elongatus subsp. fluitans C.B. Hellquist $\mathcal{E}$ S.W.L. Jacobs, subsp. nov.

Subspecie elongato affinis, sed foliis plerumque natantibus differt.

Holotype: Queensland: Pine River near Petrie, S.T. Blake 2060, Dec 1930 (BRI).

Aponogeton elongatus forma latifolius H. Bruggen, Blumea 17: 133, 1969, (L).

Holotype: Queensland: Narangba, Sidling Creek, Gillieatt 151, 8 April 1964 (L). Isotype BRI. 
Floating leaves common, 9-19 cm long, 2.2-3.5 cm wide, petiole to $90 \mathrm{~cm}$ long.

Distribution: localised in creeks and streams in the Petrie area of SE Queensland.

Selected specimens examined: Queensland: North Pine River, Petrie, 18 miles [30 km] N of Brisbane, S.T. Blake 2060, Dec 1930 (BRI); Sideling Creek, Petrie, S.T. Blake 21022, 6 Oct 1959 (BRI, MEL, NSW); Mt Coot-tha Botanic Gardens, Brisbane, S. Jacobs 2954, 7 Feb 1977 (NSW); Oyster Bay, cultivated, originally from a Brisbane collector, A.N. Rodd \& O. Campbell s.n., 18 Nov 1967 (NSW).

Grows in freshwater rivers and streams through rainforest. Flowers and fruits from October through April.

This subspecies is named for the distinctive floating leaves; from the Latin fluito, float.

This subspecies might be mistaken for the newly described tropical species A. euryspermus and A. vanbruggenii. Bruggen (1969) included two specimens of A. vanbruggenii in his concept of $A$. elongatus forma latifolius. A. elongatus subsp. fluitans is easily distinguished from the other two taxa by the distinctive seed shape and coat. All three may produce floating leaves.

Aponogeton elongatus was previously considered a widely ranging species in Australia, growing from the Kimberley region of Western Australia south and east to the northeast corner of New South Wales. With this new treatment, specimens that we here describe as $A$. euryspermus and A. vanbruggenii are removed from A. elongatus, restricting it to the northeast portion of New South Wales and southeastern Queensland, with a few populations in the Iron Range region of Cape York Peninsula.

\section{Acknowledgments}

We thank Lance Smith for his observations and specimens of various species under cultivation, Karen Wilson for providing the Latin diagnoses, Nick Cuartero for information on A. proliferus, Bill Lavarack from the Queensland National Parks for help in obtaining collection permits, the International Water Lily Society for contributing funds towards expenses for fieldwork, and the Royal Botanic Gardens, Sydney for the support of C. B. Hellquist as a Visiting Research Fellow during his stay in Sydney. We also thank John Clarkson for help in the field and for his comments on the manuscript, and Frank Zofrea, Geoff Sainty, Greg Keighery and Nick Romanowski for providing critical information and/or specimens.

\section{References}

Aston, H.I. (1973) Aquatic Plants of Australia. (Melbourne University Press: Melbourne).

Baas, P. (1985) Vegetative anatomy. Pp 3-4 in Bruggen, H.W.E. van, Monograph of the genus Aponogeton (Aponogetonaceae). Bibliotheca Botanica Band XXXIII, Heft 137.

Bouman, F. (1985) Embryology. Pp 4-9 in Bruggen, H.W.E. van, Monograph of the genus Aponogeton (Aponogetonaceae). Bibliotheca Botanica Band XXXIII, Heft 137.

Bruggen, H.W.E. van (1969) Revision of the genus Aponogeton (Aponogetonaceae): III. The species of Australia. Blumea 17: 121-137.

Bruggen, H.W.E. van (1973) Revision of the genus Aponogeton (Aponogetonaceae): VI. The species of Africa. Bull. Jard. Bot. Nat. Belg. 43: 193-233.

Bruggen, H.W.E. van (1985) Monograph of the genus Aponogeton (Aponogetonaceae). Bibliotheca Botanica Band XXXIII, Heft 137.

Tomlinson, P.B. (1982) Anatomy of the Monocotyledons. VII Helobiae (Alismatidae). (Claredon Press: Oxford). 
